\title{
Selective aerobic oxidation of alcohols by a mesoporous graphitic carbon nitride/ $N$-hydroxyphthalimide system under visible-light illumination at room temperature
}

\author{
Pengfei Zhang, Jiang Deng, Jianyong Mao, Haoran Li, Yong Wang* \\ ZJU-NHU United Research \& Development Center, Department of Chemistry, Zhejiang University, Hangzhou 310058, Zhejiang, China
}

\section{A R T I C L E I N F O}

Article history:

Received 22 March 2015

Accepted 18 April 2015

Published 20 September 2015

\section{Keywords:}

Aerobic oxidation

Benzyl alcohol

$N$-hydroxyphthalimide

Radical

Carbon nitride

\begin{abstract}
A B S T R A C T
By combination of photocatalysis and organocatalysis, a metal-free system composed of mesoporous graphitic carbon nitride (mpg- $\mathrm{C}_{3} \mathrm{~N}_{4}$ ) and $N$-hydroxyphthalimide (NHPI) offers an efficient and environmentally friendly method for the oxidation of alcohols at room temperature. As a wide-band gap semiconductor, $\mathrm{mpg}-\mathrm{C}_{3} \mathrm{~N}_{4}$ absorbs visible light and uses the energy to activate NHPI, resulting in high catalytic activity in the subsequent oxidation of alcohols. Interestingly, the main oxidation product of benzyl alcohol can be tuned from benzoic acid to benzaldehyde by increasing the ratio of mpg- $\mathrm{C}_{3} \mathrm{~N}_{4}$ in the catalyst system. To further understand the reaction route, electron spin resonance and Fourier transform infrared measurements were carried out, confirming that active oxygen and phthalimide $\mathrm{N}$-oxyl radicals formed in the mpg- $\mathrm{C}_{3} \mathrm{~N}_{4} / \mathrm{NHPI}$ system. Based on these results, a catalytic mechanism for the mpg- $\mathrm{C}_{3} \mathrm{~N}_{4} / \mathrm{NHPI}$ system was proposed. Moreover, this metal-free system also works well for the oxidation of various aromatic alcohols with good selectivity for aldehydes or ketones.
\end{abstract}

(C) 2015, Dalian Institute of Chemical Physics, Chinese Academy of Sciences. Published by Elsevier B.V. All rights reserved.

\section{Introduction}

The selective oxidation of alcohols is widely recognized as one of the most fundamental transformations in both laboratory and industrial synthetic chemistry because the corresponding carbonyl compounds serve as important and versatile intermediates for the synthesis of fine chemicals [1-4]. Traditionally, non-catalytic methods with stoichiometric, toxic, corrosive and expensive oxidants such as hypochlorite, dichromate, permanganate, and peroxy acids have been widely used for selective oxidation of alcohols [5]. From both economic and environmental viewpoints, the development of effective alcohol oxidation processes that use clean, inexpensive and at- om-efficient oxidants, such as molecular oxygen $\left(\mathrm{O}_{2}\right)$ [6-8], to convert alcohols to carbonyl compounds under mild conditions $\left(25^{\circ} \mathrm{C}, 1 \mathrm{~atm} \mathrm{O}_{2}\right)$ is an attractive prospect. In the past decade, extensive research to develop active catalysts for $\mathrm{O}_{2}$ activation has produced a number of catalytic systems, most of which contain metals including $\mathrm{Ru}$ [9-11], Pd [12-18], Cu [19-20], and $\mathrm{Ti}$ [21-23]. Recently, increasing attention has been paid to the development of metal-free catalysts for oxidation processes, mainly to minimize environmental issues.

Carbon nitrides are fascinating materials that have attracted worldwide attention [24-29]. Mesoporous graphitic carbon nitride (mpg- $\left.\mathrm{C}_{3} \mathrm{~N}_{4}\right)$ is especially attractive as a heterogeneous catalyst because of its accessible porous framework with a

\footnotetext{
* Corresponding author. Tel: +86-571-88273551; Fax: +86-571-87951895; E-mail: chemwy@zju.edu.cn This work was supported by the National Natural Science Foundation of China (21376208), the Zhejiang Provincial Natural Science Foundation for Distinguished Young Scholars of China (LR13B030001), the Specialized Research Fund for the Doctoral Program of Higher Education (J20130060), the Fundamental Research Funds for the Central Universities, and the Program for Zhejiang Leading Team of S\&T Innovation. DOI: 10.1016/S1872-2067(15)60871-3 | http://www.sciencedirect.com/science/journal/18722067 | Chin. J. Catal., Vol. 36, No. 9, September 2015
} 
large surface area [30-34]. The most active system previously identified in mpg- $\mathrm{C}_{3} \mathrm{~N}_{4}$ is in fact presumed to be a defective $\mathrm{N}$-bridged "poly(tri-s-triazine)" that forms $\pi$-conjugated planar layers. These $\pi$-bonded planar $\mathrm{C}-\mathrm{N}$-C-layers with uncondensed amino groups possess a well-developed semiconductor band structure and can participate in $\mathrm{H}-\mathrm{N}$ or $\mathrm{H}-\pi$ interactions, either as a donor (valence band with the $\pi^{*}$-orbital) or acceptor (conduction band with the $\pi$-orbital). Such interactions are stronger than dissipative interactions and are expected to be able to anchor substrates or products and increase the degree of selectivity via orientation and pattern interaction, which makes mpg- $\mathrm{C}_{3} \mathrm{~N}_{4}$ suitable as a catalyst or catalyst support with active bonding sites [35]. In addition, because of its appropriate band gap of $2.7 \mathrm{eV}$, mpg- $\mathrm{C}_{3} \mathrm{~N}_{4}$ can activate $\mathrm{O}_{2}$ by a one-electron transfer reaction under visible-light irradiation [36-38]. For example, under illumination, mpg- $\mathrm{C}_{3} \mathrm{~N}_{4}$ exhibited catalytic activity towards the oxidation of benzyl alcohol, albeit under relatively harsh conditions $\left(100{ }^{\circ} \mathrm{C}, 8\right.$ bar $\mathrm{O}_{2}$ and high-intensity visible light) [39]. Therefore, the active surface structure together with the appropriate band gap make mpg- $\mathrm{C}_{3} \mathrm{~N}_{4}$ a promising candidate to serve as a visible-light one-electron transfer starter for oxygenation. This inspired us to consider that a combination of mpg- $\mathrm{C}_{3} \mathrm{~N}_{4}$ and organocatalyst may provide an effective catalytic system for alcohol oxidation under mild conditions.

In recent years, $N$-hydroxyphthalimide (NHPI) has been used as a valuable catalyst for the efficient aerobic oxidation of various organic compounds in the presence of co-catalysts, most of which were metallic compounds [40-48]. More recently, we developed a photocatalytic system consisting of bulk carbon nitride $\left(\mathrm{g}-\mathrm{C}_{3} \mathrm{~N}_{4}\right)$ and NHPI for the allylic oxidation of $\mathrm{C}-\mathrm{H}$ bonds [49]. Compared with $\mathrm{g}-\mathrm{C}_{3} \mathrm{~N}_{4}\left(S_{\mathrm{BET}}=8 \mathrm{~m}^{2} / \mathrm{g}\right)$, mpg- $\mathrm{C}_{3} \mathrm{~N}_{4}\left(S_{\mathrm{BET}}=190 \mathrm{~m}^{2} / \mathrm{g}\right)$ can in principle markedly enhance the photochemical properties of such a catalyst system because of its increased surface area and multiple scattering effects compared with g- $\mathrm{C}_{3} \mathrm{~N}_{4}$. Here, we report a mpg- $\mathrm{C}_{3} \mathrm{~N}_{4} / \mathrm{NHPI}$ system that behaves as a non-metal photocatalytic system with excellent activity towards the oxidation of alcohol under mild conditions $\left(25^{\circ} \mathrm{C}, 1 \mathrm{~atm} \mathrm{O}_{2}\right)$.

\section{Experimental}

\subsection{Materials and instruments}

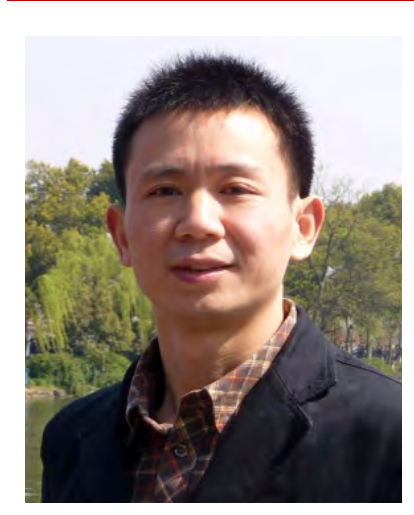

Unless otherwise stated, all solvents and chemicals were of analytical grade and used without further treatment. NHPI (99\%) was provided by Zhejiang Nhu Co., Ltd, China. Benzoyl peroxide (99\%), anthraquinone (99\%) and cyclohexanol (>99\%) were purchased from Sinopharm Chemistry. Co., Ltd. Benzyl alcohol (BA; >99\%), benzaldehyde (>99\%) and acetonitrile $(>99.5 \%)$ were purchased from Shanghai Lingfeng Chemical Reagent Co., Ltd. 4-Methylbenzyl alcohol (98\%), 4-methoxybenzyl alcohol (98\%), 4-nitrobenzyl alcohol (98\%), benzhydrol (99\%) and 4,4'-dichlorobenzhydrol (98\%) were purchased from Aladdin Chemistry Co., Ltd, China. We synthesized mpg- $\mathrm{C}_{3} \mathrm{~N}_{4}$ as reported previously [50]. All gas chromatography (GC) experiments were carried out and recorded using a Shimadzu GC-2010 chromatograph with a flame ionization detector. The structures of products and by-products were identified using an HP6890 GC/MS spectrometer by comparing retention times and fragmentation patterns with those of authentic samples. A household w-filament bulb $(250 \mathrm{~W}$, cost of $\sim$ \$) with a 420-nm cut-off filter was used as a visible-light source to irradiate the reaction system.

\subsection{Typical procedure for the catalytic oxidation of alcohols}

In a typical oxidation experiment, substrate $(10 \mathrm{mmol})$, catalyst (as described in Table 1) and acetonitrile (20 mL) were added to a 25-mL three-neck round bottom glass reactor, which was fitted with a magnetic stirrer and $\mathrm{O}_{2}$ inlet tube. The reaction was performed at $25^{\circ} \mathrm{C}$ in a water bath with magnetic stirring. $\mathrm{O}_{2}$ was introduced into the reactor at a constant flow rate $(5 \mathrm{~mL} / \mathrm{min})$. A household $\mathrm{w}$-filament bulb $(250 \mathrm{~W})$ and 420 -nm cut-off filter were placed $\sim 10 \mathrm{~cm}$ from the reactor as a visible-light source. To carry out the reaction in the dark, the glass reactor was covered with aluminum foil. After completion of the reaction, toluene was added to the mixture as an internal standard. Then, mpg- $\mathrm{C}_{3} \mathrm{~N}_{4}$ was removed by filtration and the reaction mixture was injected into the GC for analysis.

\section{Results and discussion}

\subsection{Catalytic alcohol oxidation using the $m p g-C_{3} N_{4} / N H P I$ system.}

We tested the catalytic activity of the photooxidation system consisting of mpg- $\mathrm{C}_{3} \mathrm{~N}_{4}$ and NHPI using BA as a probe molecule.

\begin{abstract}
Yong Wang (Department of Chemistry, Zhejiang University) received the Catalysis Rising Star Award in 2014, which was presented by The Catalysis Society of China. Prof. Dr. Yong Wang studied chemical engineering at Xiangtan University from 1998 to 2002. He received his Ph.D. degree from Zhejiang University in 2007. After a postdoctoral stay at the Department of Chemistry, Zhejiang University, he joined the Max Planck Institute for Colloids and Interfaces in Potsdam/Germany in 2009. He rejoined Zhejiang University and became a Professor for Chemistry in 2011. His research focuses on carbon nano materials and their applications in heterogeneous catalysis and energy storage and conversion. He has published more than 60 peer-reviewed papers with over 2100 citations.
\end{abstract}


Table 1

Results for the oxidation of BA with mpg- $\mathrm{C}_{3} \mathrm{~N}_{4}$ and NHPI.

\begin{tabular}{|c|c|c|c|c|c|c|c|}
\hline \multirow{2}{*}{ Entry } & \multicolumn{4}{|c|}{ Catalyst $^{\mathrm{a}}$} & \multirow{2}{*}{$\begin{array}{c}\text { Conversion } \\
(\%)\end{array}$} & \multicolumn{2}{|c|}{ Selectivity (\%) } \\
\hline & \multicolumn{2}{|c|}{$\mathrm{C}_{3} \mathrm{~N}_{4}$} & \multicolumn{2}{|c|}{$>\mathrm{N}-\mathrm{OH}$} & & $-\mathrm{CHO}$ & $-\mathrm{COOH}$ \\
\hline 1 & $\mathrm{CN}$ & $100 \mathrm{mg}$ & NHPI & $10 \%$ & 99 & 7 & 92 \\
\hline 2 & $\mathrm{CN}$ & $100 \mathrm{mg}$ & - & & 1 & 98 & - \\
\hline 3 & - & & NHPI & $10 \%$ & 2 & 98 & - \\
\hline 4 & g-CN & $100 \mathrm{mg}$ & NHPI & $10 \%$ & 20 & 96 & - \\
\hline $5^{b}$ & $\mathrm{CN}$ & $100 \mathrm{mg}$ & NHPI & $10 \%$ & 99 & 8 & 90 \\
\hline $6^{c}$ & $\mathrm{CN}$ & $100 \mathrm{mg}$ & NHPI & $10 \%$ & 98 & 6 & 86 \\
\hline $7 \mathrm{~d}$ & $\mathrm{CN}$ & $100 \mathrm{mg}$ & NHPI & $10 \%$ & 99 & 10 & 87 \\
\hline 8 & $\mathrm{CN}$ & $100 \mathrm{mg}$ & NHPI & $5 \%$ & 44 & 98 & - \\
\hline 9 & $\mathrm{CN}$ & $200 \mathrm{mg}$ & NHPI & $10 \%$ & 85 & 82 & 13 \\
\hline
\end{tabular}

Reaction conditions: BA $(10 \mathrm{mmol})$, acetonitrile $(20 \mathrm{~mL}), 1 \mathrm{~atm} \mathrm{O}_{2}$, $25{ }^{\circ} \mathrm{C}, \mathrm{W}$-bulb $(250 \mathrm{~W})$ with a cut-off filter $>420 \mathrm{~nm}$ as the visible-light source, $28 \mathrm{~h}$. ${ }^{\text {a }} \mathrm{CN}$ : mpg- $\mathrm{C}_{3} \mathrm{~N}_{4}$, g-CN: g- $\mathrm{C}_{3} \mathrm{~N}_{4}$. ${ }^{\text {b }}$ Second run to test the reusability of $\mathrm{CN}$. ${ }^{\mathrm{c}}$ Third run to test the reusability of catalyst. ${ }^{\mathrm{d}}$ Fourth run to test the reusability of catalyst.

All reactions were performed at room temperature and ambient pressure using a household $\mathrm{W}$-bulb $(250 \mathrm{~W}$, with a cut-off filter $>420 \mathrm{~nm}$ ) as the visible-light source. Air or $\mathrm{O}_{2}$ was introduced to the reaction systems as the ultimate oxidant.

The conversion of BA reached $99 \%$, while the selectivity toward benzoic acid was $92 \%$ for the mpg- $\mathrm{C}_{3} \mathrm{~N}_{4} / \mathrm{NHPI}$ system under visible-light illumination (Table 1, entry 1). In contrast, only very low conversion of BA was observed in the absence of either mpg- $\mathrm{C}_{3} \mathrm{~N}_{4}$ or NHPI (Table 1, entries 2 and 3) under the same reaction conditions. These results indicate that mpg- $\mathrm{C}_{3} \mathrm{~N}_{4}$ and NHPI are indeed coupled to form an effective catalyst system for the aerobic oxidation of BA. Notably, the use of mpg- $\mathrm{C}_{3} \mathrm{~N}_{4}$ leads to considerably enhanced conversion compared with that of the $\mathrm{g}-\mathrm{C}_{3} \mathrm{~N}_{4} / \mathrm{NHPI}$ system (Table 1 , entry 4 ). The enhanced catalytic activity of the mpg- $\mathrm{C}_{3} \mathrm{~N}_{4} / \mathrm{NHPI}$ system compared with that of $\mathrm{g}-\mathrm{C}_{3} \mathrm{~N}_{4} / \mathrm{NHPI}$ could be attributed to the better interaction between NHPI and carbon nitride materials promoting the formation of phthalimide $\mathrm{N}$-oxyl (PINO) radicals. The oxidation afforded only $14 \%$ conversion of BA when it was carried out in the dark. These results reveal that visible light was important for the activity of this catalytic system, particularly for mpg- $\mathrm{C}_{3} \mathrm{~N}_{4}$. As a semiconductor material, mpg- $\mathrm{C}_{3} \mathrm{~N}_{4}$ is considered to act an electron-transfer mediator under visible-light illumination in the current system.

As a heterogeneous catalyst, mpg- $\mathrm{C}_{3} \mathrm{~N}_{4}$ can be easily recovered by filtration, washed and then dried at $100{ }^{\circ} \mathrm{C}$. The conversion and selectivity of mpg- $\mathrm{C}_{3} \mathrm{~N}_{4} / \mathrm{NHPI}$ containing mpg- $\mathrm{C}_{3} \mathrm{~N}_{4}$ used in three consecutive runs were virtually identical to those in the initial experiment with fresh mpg- $\mathrm{C}_{3} \mathrm{~N}_{4}$, which is a prerequisite for practical application (Table 1, entries 5-7). In previous publications, several non-metal co-catalysts have been combined with NHPI as active systems for oxidation [51]. Compared with these systems [52-54], the mpg- $\mathrm{C}_{3} \mathrm{~N}_{4} / \mathrm{NHPI}$ system exhibits promising catalytic activity (Table 2).

To clarify the roles of mpg- $\mathrm{C}_{3} \mathrm{~N}_{4}$ and NHPI in this system, we performed some comparative experiments. When the molar amount of NHPI was halved (5 mol\%), less BA was oxidized (44\%) and benzaldehyde was formed with 98\% selectivity (Table 1, entry 8), which indicates that benzaldehyde is a resolvable intermediate of the oxidation process. Adding twice
Table 2

Results for the oxidation of BA with different catalysts.

\begin{tabular}{lcccc}
\hline \multirow{2}{*}{ Entry } & \multirow{2}{*}{ Co-catalyst } & \multicolumn{2}{c}{$\begin{array}{c}\text { Conversion } \\
(\%)\end{array}$} & \multicolumn{2}{c}{ Selectivity (\%) } \\
\cline { 4 - 6 } & AQ $1 \%$ & 7 & - CHO & $-\mathrm{COOH}$ \\
2 & BPO 1\% & 6 & 93 & 5 \\
3 & CN 100 mg & 99 & 700 & - \\
\hline
\end{tabular}

Reaction conditions: BA (10 mmol), NHPI (10\%), acetonitrile (20 mL), 1 atm $\mathrm{O}_{2}, 25{ }^{\circ} \mathrm{C}, \mathrm{W}$-bulb $(250 \mathrm{~W})$ and cut-off filter $>420 \mathrm{~nm}$ as the visible-light source, 28 h. $\mathrm{CN}$ : $m p g-\mathrm{C}_{3} \mathrm{~N}_{4}, \mathrm{AQ}$ : anthraquinone, BPO: benzoyl peroxide.

the amount of mpg- $\mathrm{C}_{3} \mathrm{~N}_{4}$ (200 mg) also gave benzaldehyde with a selectivity of $82 \%$ instead of BA as main product, but the conversion decreased to $85 \%$ (Table 1, entry 9). These results suggest that mpg- $\mathrm{C}_{3} \mathrm{~N}_{4}$ plays an important role in the selectivity for benzaldehyde. Therefore, we analyzed the effect of mpg- $\mathrm{C}_{3} \mathrm{~N}_{4}$ on the selectivity for benzaldehyde more systematically.

As shown in Fig. 1, increasing the amount of mpg- $\mathrm{C}_{3} \mathrm{~N}_{4}$ leads to higher selectivity for benzaldehyde. Under harsh conditions, benzaldehyde is a reactive intermediate and is easily oxidized further to BA. However, our present catalytic system works at room temperature, and thereby has a wide operation window for selective oxidation. The preferred selectivity for aldehydes should also be related to the different abilities of products to adsorb on mpg- $\mathrm{C}_{3} \mathrm{~N}_{4}$. Fig. 2 reveals that the amount of BA adsorbed by mpg- $\mathrm{C}_{3} \mathrm{~N}_{4}$ at equilibrium is about three times that of benzaldehyde, possibly because of the formation of $\mathrm{O}-\mathrm{H}$... $\mathrm{N}$ or $0-H . . . \pi$ interactions, as described in a previous report [35]. It seems reasonable that the adsorbed BA is easily oxidized to benzaldehyde by the active species on the surface of mpg- $C_{3} \mathrm{~N}_{4}$. The produced benzaldehyde with a weaker H-bridge donor than that of BA would then be replaced by a more strongly binding BA molecule, avoiding over-oxidation to some degree.

\subsection{Mechanism of the mpg- $C_{3} N_{4} / N H P I$ system}

To further understand the reaction cycle of the mpg- $\mathrm{C}_{3} \mathrm{~N}_{4}$ /NHPI system, we investigated its catalytic mecha-

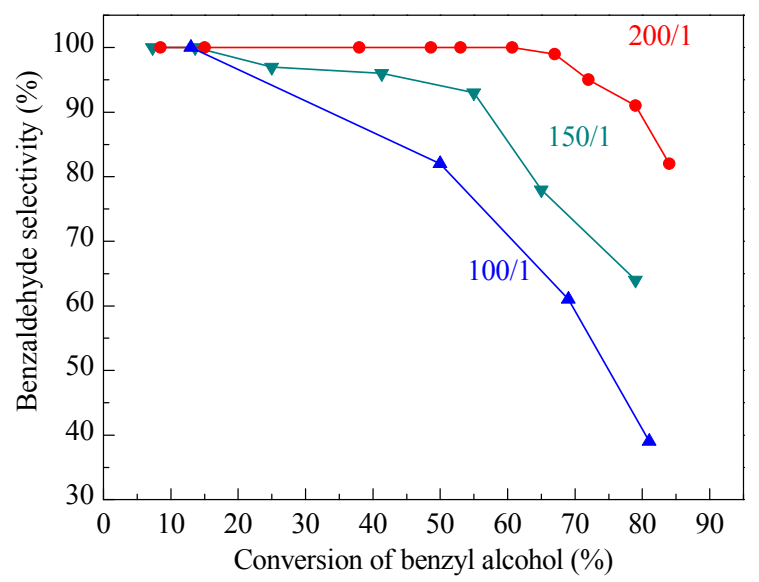

Fig. 1. Plot of the selectivity for benzaldehyde against the conversion of BA for the oxidation of BA catalyzed by different ratios of mpg- $\mathrm{C}_{3} \mathrm{~N}_{4}(\mathrm{mg}$ and NHPI (mmol). 


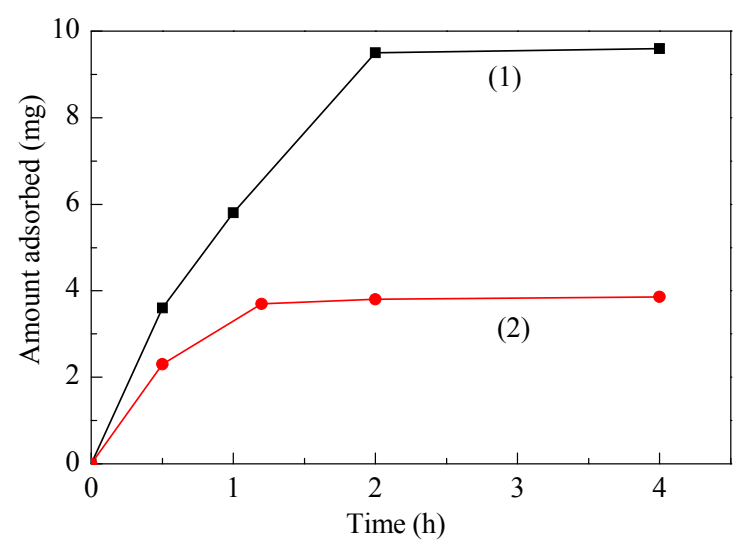

Fig. 2. Effect of contact time on the adsorption of BA (1) and benzaldehyde (2) on mpg- $\mathrm{C}_{3} \mathrm{~N}_{4}$. Experiment conditions: $\mathrm{mpg}-\mathrm{C}_{3} \mathrm{~N}_{4}(30 \mathrm{mg})$, BA or benzaldehyde $(0.1 \mathrm{mmol})$ solution in $\mathrm{CH}_{3} \mathrm{CN}(10 \mathrm{~mL}), 20^{\circ} \mathrm{C}$.

$$
\begin{aligned}
\text { (1) } \mathrm{mpg}_{-} \mathrm{C}_{3} \mathrm{~N}_{4} \stackrel{\text { vis. light }}{\longrightarrow} & \\
\mathrm{O}_{2}+\mathrm{e}^{-} & \longrightarrow \mathrm{mpg}^{-} \mathrm{C}_{3} \mathrm{~N}_{4}\left(\mathrm{~h}^{+}, \mathrm{e}^{-}\right) \\
& \mathrm{O}_{2}^{-}
\end{aligned}
$$

(2)

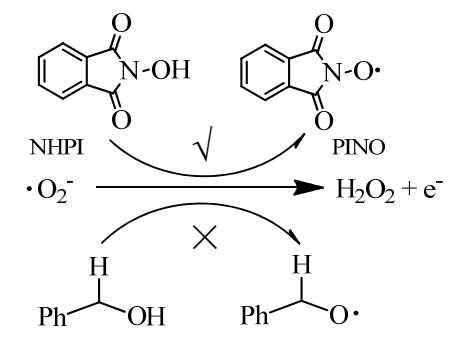

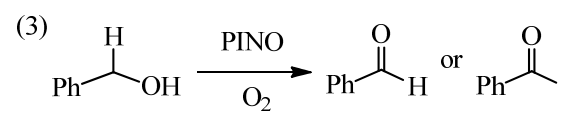

Scheme 1. A possible reaction mechanism for the catalytic cycle of the mpg- $\mathrm{C}_{3} \mathrm{~N}_{4}$ /NHPI system.

nism (Scheme 1). Under visible-light illumination, irradiated electrons from the conduction band of mpg- $\mathrm{C}_{3} \mathrm{~N}_{4}$ reduced $\mathrm{O}_{2}$ to the ${ }^{\cdot} \mathrm{O}_{2}{ }^{-}$radical, because the signals for the $\mathrm{DMPO}-{ }^{-} \mathrm{O}_{2}-$ adduct were detected in electron spin resonance (ESR) spectra (Fig. 3, L1). Under the conditions used, the produced $\cdot \mathrm{O}_{2}{ }^{-}$radical cannot induce alcohol oxidation by $\mathrm{H}$ abstraction because only trace product (1\%) was observed for BA oxidation catalyzed by mpg- $\mathrm{C}_{3} \mathrm{~N}_{4}$ alone [39]. The ESR signals for the DMPO- $\mathrm{O}_{2}{ }^{-}$adduct showed only minor change after adding BA to the mpg- $\mathrm{C}_{3} \mathrm{~N}_{4}$ system (Fig. 3, L2). However, the intensity of these signals clearly decreased after adding NHPI to mpg- $\mathrm{C}_{3} \mathrm{~N}_{4}$, which was attributed to the reaction between the $\mathrm{O}_{2}{ }^{-}$radical and NHPI (Fig. 3, L3). Based on these results, it can be concluded that the $\cdot \mathrm{O}_{2}-$ radical can abstract the $\mathrm{O}-\mathrm{H}$ hydrogen from NHPI to generate the PINO radical.

Subsequently, the PINO radical smoothly oxidized BA to benzaldehyde or benzoic acid with $\mathrm{O}_{2}$ as confirmed previously $[46,55,56]$. A careful Fourier transform infrared (FT-IR) investigation of the mpg- $\mathrm{C}_{3} \mathrm{~N}_{4} / \mathrm{NHPI}$ system in the presence of $\mathrm{O}_{2}$ under visible-light irradiation revealed a broad peak around $3250 \mathrm{~cm}^{-1}$ that was not observed in the mpg- $\mathrm{C}_{3} \mathrm{~N}_{4}$ and NHPI

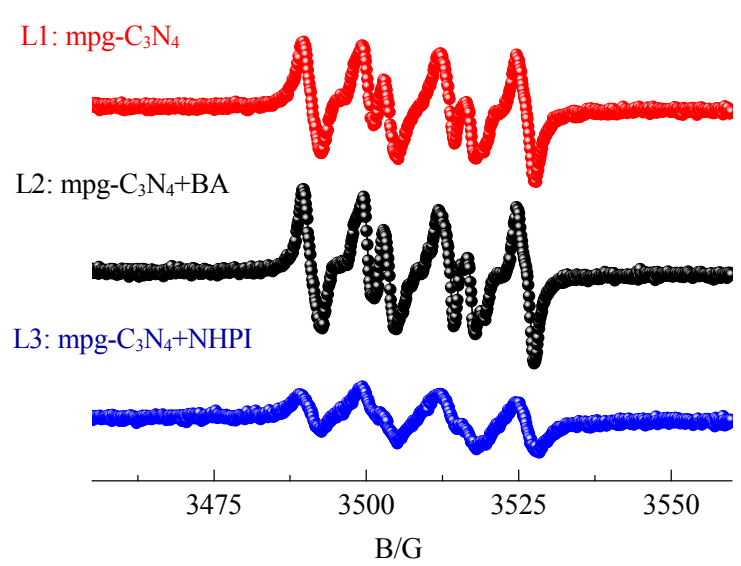

Fig. 3. Changes in the DMPO spin-trapping ESR spectra for mpg- $\mathrm{C}_{3} \mathrm{~N}_{4}(4$ $\mathrm{mg})$, mpg- $\mathrm{C}_{3} \mathrm{~N}_{4}(4 \mathrm{mg}) / \mathrm{BA}(10 \mu \mathrm{L})$ and $\mathrm{mpg}-\mathrm{C}_{3} \mathrm{~N}_{4}(4 \mathrm{mg}) / \mathrm{NHPI}(10 \mathrm{mg})$ in $\mathrm{CH}_{3} \mathrm{CN}(1 \mathrm{~mL})$. Each mixture was stirred for 10 min with $\mathrm{O}_{2}$ bubbling and visible-light irradiation and then put in a quartz tube for ESR measurement.

alone (Fig. 4). This new peak is attributed to the stretching vibration of $-\mathrm{OH}$ in $>0-\mathrm{H} \cdots \cdots \cdot \mathrm{O}-\mathrm{N}<$. Because of the high dipole moment of the nitroxyl functional group (6.7 D for PINO), PINO readily forms $\mathrm{O}-\mathrm{H} \cdot \cdots \cdot \cdot \mathrm{O}-\mathrm{N}$ intermolecular hydrogen bonds with proton donors [57]. In fact, similar hydrogen bonds between 2,2,6,6-tetramethylpiperidine- $N$-oxyl (TEMPO) and phenol have been observed with a broad peak at ca. $3280 \mathrm{~cm}^{-1}$ in FT-IR spectra [58]. As time elapsed, the intensity of the broad peak increased. These FT-IR results further confirm the generation of PINO radicals, which was promoted by visible-light irradiation of $\mathrm{mpg}_{-} \mathrm{C}_{3} \mathrm{~N}_{4}$.

\subsection{Alcohol oxidation by the mpg- $C_{3} N_{4} /$ NHPI system}

To investigate the scope of this catalytic system, its ability to catalyze oxidation of various aromatic alcohols was investigated (Table 3). Three representative para-substituted aromatic alcohols were transformed to their corresponding aldehydes with good selectivity. Interestingly, the oxidation of

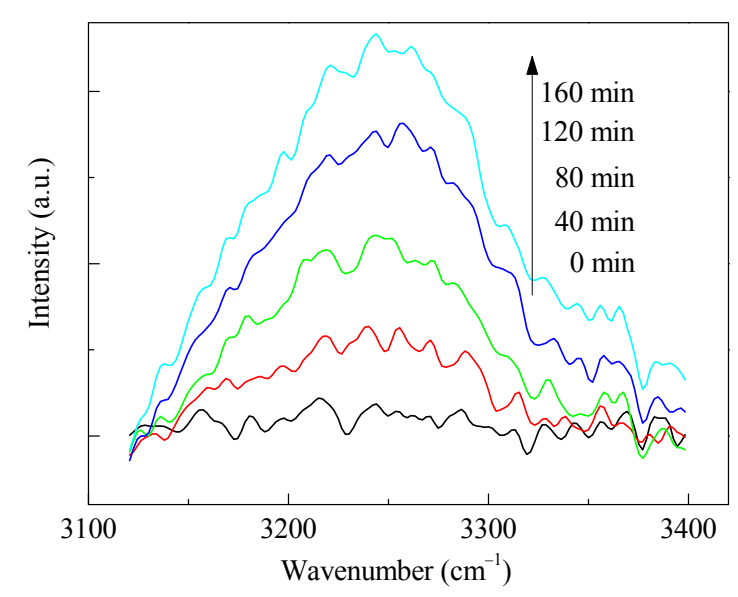

Fig. 4. FT-IR spectra of mpg- $\mathrm{C}_{3} \mathrm{~N}_{4} / \mathrm{NHPI}$ in $\mathrm{CH}_{3} \mathrm{CN}$ at $25{ }^{\circ} \mathrm{C}$ in the presence of $\mathrm{O}_{2}$ under visible-light irradiation $(>420 \mathrm{~nm})$. 
Table 3

Oxidation of various alcohols with $m p g-\mathrm{C}_{3} \mathrm{~N}_{4}$ and NHPI.

\begin{tabular}{lllll} 
Entry & $\begin{array}{c}\text { Time } \\
(\mathrm{h})\end{array}$ & $\begin{array}{c}\text { Conv. } \\
(\%)\end{array}$ & $\begin{array}{c}\text { Sel. } \\
(\%)\end{array}$ \\
\hline & $(4-\mathrm{Cl}-\mathrm{Ph})_{2} \mathrm{CHOH}$ & 22 & 89 & 94 \\
\hline
\end{tabular}

Reaction conditions: Alcohol substrate $(10 \mathrm{mmol}), \mathrm{mpg}-\mathrm{C}_{3} \mathrm{~N}_{4}(200 \mathrm{mg})$, NHPI ( $1 \mathrm{mmol})$, acetonitrile $(20 \mathrm{~mL}), 1 \mathrm{~atm} \mathrm{O}_{2}, 25^{\circ} \mathrm{C}$, visible light $>420$ nm.

$p$-methylbenzyl alcohol yielded the synthetically valuable $p$-methylbenzaldehyde (Table 3, entry 1). After $17 \mathrm{~h}$ at room temperature, the coupled system afforded a high yield in the oxidation of cyclohexanol (Table 3, entry 4). The oxidation of benzhydrol also proceeded smoothly, giving $100 \%$ conversion in $15 \mathrm{~h}$ (Table 3, entry 5). Relatively good results were achieved using a benzhydrol analog as a substrate (Table 3, entry 6). Thus, it is obviously possible to extend the scope of the mpg- $\mathrm{C}_{3} \mathrm{~N}_{4} / \mathrm{NHPI}$ system to the selective oxidation of other alcohols.

\section{Conclusions}

A visible-light-activated non-metal system that catalyzes selective oxidation of alcohols with good conversion at room temperature was developed. Compared with the g- $\mathrm{C}_{3} \mathrm{~N}_{4} / \mathrm{NHPI}$ system, the current mpg- $\mathrm{C}_{3} \mathrm{~N}_{4} / \mathrm{NHPI}$ system exhibited higher catalytic activity. Each of the three components of mpg- $\mathrm{C}_{3} \mathrm{~N}_{4}$ NHPI and visible light make a unique contribution to the system performance. On the one hand, mpg- $\mathrm{C}_{3} \mathrm{~N}_{4}$ not only induces a one-electron transfer under visible-light irradiation, but also acts as a host material with a specific $2 \mathrm{D}$ surface structure to control the reaction selectivity to some extent. On the other hand, the PINO radical as a redox center demonstrates powerful catalytic oxidation activity. During the mechanistic investigation, ${ }^{\circ} \mathrm{O}_{2}$ - and PINO radicals were identified as the active species in the catalytic process by ESR and FT-IR measurements. We believe that many visible-light-responsive materials could be coupled with organocatalysts in a similar fashion to that described here to provide fascinating catalytic systems.

\section{References}

[1] Sheldon R A, Arends I W C E, Brink G J T, Dijksman A. Acc Chem Res, 2002, 35: 774

[2] Mallat T, Baiker A. Chem Rev, 2004, 104: 3037

[3] Ryland B L, Stahl S S. Angew Chem Int Ed, 2014, 53: 8824

[4] Wang L Y, Li J, Yang H, Lv Y, Gao S. J Org Chem, 2012, 77: 790

[5] Hill C L. Advance in Oxygenated Process. JAI, London, 1998

[6] Mao J Y, Li N, Li H R, Hu X B. J Mol Catal A, 2006, 258: 178

[7] Hu X B, Mao J Y, Sun Y, Chen H, Li H R. Catal Commun, 2009, 10: 1908

[8] Parmeggiani C, Cardona F. Green Chem, 2012, 14: 547

[9] Dijksman A, Marino-González A, Payeras A M, Arends I W C E, Sheldon R A. J Am Chem Soc, 2001, 123: 6826

[10] Yamaguchi K, Mori K, Mizugaki T, Ebitani K, Kaneda K. J Am Chem Soc, 2000, 122: 7144

[11] Zhan B J, White M A, Sham T K, Pincock J A, Doucet R J, Rao K V R, Robertson K N, Cameron T S. J Am Chem Soc, 2003, 125: 2195

[12] Mori K, Hara T, Mizugaki T, Ebitani K, Kaneda K. J Am Chem Soc, 2004, 126: 10657

[13] Parlett C M A, Bruce D W, Hondow N S, Lee A F, Wilson K. ACS Catal, 2011, 1: 636

[14] Gligorich K M, Sigman M S. Chem Commun, 2009, 26: 3854

[15] Mueller J A, Goller C P, Sigman M S. J Am Chem Soc, 2004, 126: 9724

[16] Schultz M J, Hamilton S S, Jensen D R, Sigman M S. J Org Chem, 2005, 70: 3343

[17] Bailie D S, Clendenning G M A. McNamee L, Muldoon M J. Chem Commun, 2010, 46: 7238

[18] Mizuno N, Yamaguchi K. Catal Today, 2008, 132: 18

[19] Furukawa S, Tamura A, Shishido T, Teramura K, Tanaka T. Appl Catal B, 2011, 110: 216

\section{Graphical Abstract}

Chin. J. Catal., 2015, 36: 1580-1586 doi: 10.1016/S1872-2067(15)60871-3

Selective aerobic oxidation of alcohols by a mesoporous graphitic carbon nitride/ $N$-hydroxyphthalimide system under visible-light illumination at room temperature

Pengfei Zhang, Jiang Deng, Jianyong Mao, Haoran Li, Yong Wang* Zhejiang University

Mesoporous graphitic carbon nitride and $N$-hydroxyphthalimide were used to catalyze oxidation of aromatic alcohols by oxygen under visible-light irradiation. Visible light was harnessed as an efficient energy source to induce radical oxidation at room temperature.

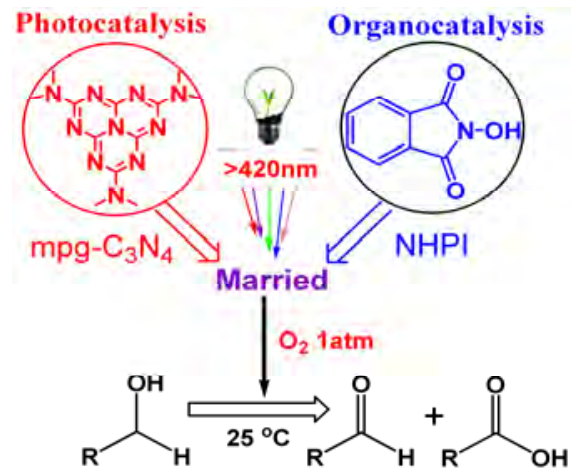


[20] Hoover J M, Stahl S S. J Am Chem Soc, 2011, 133: 16901

[21] Li R H, Kobayashi H, Guo J F, Fan J. J Phys Chem C, 2011, 115: 23408

[22] Wang Q Zhang M, Chen C C, Ma W H, Zhao J C. Angew Chem Int Ed, 2010, 49: 7976

[23] Zhang M, Chen C C, Ma W H, Zhao J C. Angew Chem Int Ed, 2008, 47: 9730

[24] Wang X C, Maeda K, Thomas A, Takanabe K, Xin G, Carlsson J M, Domen K, Antonietti M. Nat Mater, 2009, 8: 76

[25] Thomas A, Fischer A, Goettmann F, Antonietti M, Müller J O, Schlogl R, Carlsson J M. J Mater Chem, 2008, 18: 4893

[26] Wang Y, Wang X C, Antonietti M. Angew Chem Int Ed, 2012, 51: 68

[27] Zheng Y, Liu J, Liang J, Jaroniec M, Qiao S Z. Energy Environ Sci, 2012, 5: 6717

[28] Zhang Y J, Mori T, Ye J H. Sci Adv Mater, 2012, 4: 282

[29] Gong Y T, Li M M, Wang Y. ChemSusChem, 2015, 8: 931

[30] Wang Y, Zhang J S, Wang X C, Antonietti M, Li H R. Angew Chem Int Ed, 2010, 49: 3356

[31] Liu G, Niu P, Sun C H, Smith S C, Chen Z G, Lu G Q, Cheng H M. J Am Chem Soc, 2010, 132: 11642

[32] Wang Y, Li H R, Yao J, Wang X C, Antonietti M. Chem Sci, 2011, 2: 446

[33] Gong Y T, Li M M, Li H R, Wang Y. Green Chem, 2015, 17: 715

[34] Zhang P F, Li H R, Wang Y. Chem Commun, 2014, 50: 6312

[35] Wang Y, Yao J, Li H R, Su D S, Antonietti M. J Am Chem Soc, 2011, 133: 2362

[36] Yan S C, Lv S B, Li Z S, Zou Z G. Dalton Trans, 2010, 39: 1488

[37] Yan S C, Li Z S, Zou Z G. Langmuir, 2010, 26: 3894

[38] Zhang P F, Wang Y, Li H R, Antonietti M. Green Chem, 2012, 14: 1904

[39] Su F Z, Mathew S C, Lipner G, Fu X Z, Antonietti M, Blechert S,
Wang X C. J Am Chem Soc, 2010, 132: 16299

[40] Zhang P F, Wang C M, Chen Z R, Li H R. Catal Sci Technol, 2011, 1: 1133

[41] Wang C M, Wang G L, Mao J Y, Yao Z, Li H R. Catal Commun, 2010, 11: 758

[42] Coseri S. Min Rev Org Chem, 2008, 5: 222

[43] Recupero F, Punta C. Chem Rev, 2007, 107: 3800

[44] Guha S K, Obora Y, Ishihara D, Matsubara H, Ryu I, Ishii Y. Adv Synth Catal, 2008, 350: 1323

[45] Figiel P J, Sobczak J M. J Catal, 2009, 263: 167

[46] Nechab M, Kumar D N, Philouze C, Einhorn C, Einhorn J. Angew Chem Int Ed, 2007, 46: 3080

[47] Ma H, Xu J, Zhang Q H, Miao H, Wu W H. Catal Commun, 2007, 8: 27

[48] Cao Q, Dornan L M, Rogan L, Hughes N L, Muldoon M J. Chem Commun, 2014, 50: 4524

[49] Zhang P F, Wang Y, Yao J, Wang C M, Yan C, Antonietti M, Li H R. Adv Synth Catal, 2011, 353: 1447

[50] Goettmann F, Fischer A, Antonietti M, Thomas A. Angew Chem Int Ed, 2006, 45: 4467

[51] Coseri S. Catal Rev Sci Eng, 2009, 51: 218

[52] Yang G Y, Ma Y F, Xu J. J Am Chem Soc, 2004, 126: 10542

[53] Yang G Y, Zhang Q H, Miao H, Tong X L, Xu J. Org Lett, 2005, 7: 263

[54] Yao Z, Hu X B, Mao J Y, Li H R. Green Chem, 2009, 11: 2013

[55] Iwahama T, Yoshino Y, Keitoku T, Sakaguchi S, Ishii Y. J Org Chem, 2000, 65: 6502

[56] Minisci F, Punta C, Recupero F, Fontana F, Pedulli G F. Chem Commun, 2002, 688

[57] Yang X M, Zhou L P, Chen Y, Chen C, Su Y L, Miao H, Xu J. Catal Commun, 2009, 11: 171

[58] Franchi P, Lucarini M, Pedrielli P, Pedulli G F. ChemPhysChem, 2002, 3: 789

\title{
介孔石墨型氮化碳 $/ N$-羟基邻苯二甲酰亚胺组合催化体系 催化醇类化合物的选择性氧化
}

\author{
张鹏飞, 邓江，毛建拥，李浩然，王 勇* \\ 浙江大学化学系, 浙江大学-新和成联合研发中心, 浙江杭州 310058
}

摘要: 醇的氧化产品(醛和酸)是精细化工中的重要中间体. 醇类的选择性氧化无论是在基础研究还是在工业应用方面都具有非 常重要的意义. 传统的方法是使用化学计量的氧化剂(如: 高氯酸盐, 重铬酸盐, 高锰酸盐, 过氧酸)来氧化醇. 但是, 这些氧化剂具 有强腐蚀性, 价格较昂贵, 有些氧化剂还具有很强的毒性或者反应后产生大量重金属废液. 而以分子氧作为氧化剂在温和条件下 实现醇到醛的氧化具有更好的经济性也更环保. 在过去几十年里,科学家们发展了许多催化体系来活化氧气分子. 这些体系大部 分是基于钉、钯、铜和钛等金属催化剂. 近年, 考虑成本和环境因素, 越来越多的科学家把目光投向无金属催化剂来实现醇的氧 化.

石墨型氮化碳 $\left(\mathrm{g}-\mathrm{C}_{3} \mathrm{~N}_{4}\right)$ 是二维层状类石墨结构, 层内原子以共价键相连, 层与层之间由于分子间作用而堆叠在一起. 在 g- $\mathrm{C}_{3} \mathrm{~N}_{4}$ 中引入介孔 $\left(\mathrm{mpg}-\mathrm{C}_{3} \mathrm{~N}_{4}\right.$ ) 能够提高g- $\mathrm{C}_{3} \mathrm{~N}_{4}$ 的比表面积, 提供更多的活性位点. 由于 $m p g-\mathrm{C}_{3} \mathrm{~N}_{4}$ 具有半导体性质(带隙宽度为 2.7 $\mathrm{eV}$ ), 在可见光照射下能够激发出一个电子给氧气, 氧气得到电子后生成具有较高氧化活性的 $\mathrm{O}_{2}^{-}$. 这样我们就可以在比较温和的 条件下得到活性较高的氧化剂. 但是 $\mathrm{O}_{2}{ }^{-}$活性和产量有限、并且容易被猝灭, 因此我们想通过选用一个能形成比较稳定的自由基 的有机分子来 “传递氧化性” . 基于上述思考, 我们引入 $m p g-C_{3} \mathrm{~N}_{4}$ 和 $N$-羊基邻苯二甲酰亚胺(NHPI)作为组合催化体系实现光催化 和有机催化有效的结合来催化选择性氧化醇.

以苯甲醇为模型化合物、以 $m p g-\mathrm{C}_{3} \mathrm{~N}_{4} / \mathrm{NHPI}$ 作为组合型催化剂、普通的铇丝灯为光源, 在 $25^{\circ} \mathrm{C}$ 下通入 $1 \mathrm{~atm} \mathrm{O}_{2}$, 实现了醇的选 择性氧化. 通过电子自旋共振测试, 我们探测到 $\mathrm{O}_{2}{ }^{-}$自由基. 在只有 $\mathrm{mpg}^{-} \mathrm{C}_{3} \mathrm{~N}_{4}$ 的体系中, 产生的 ${ }^{\circ}{ }^{-}{ }^{-}$自由基很快被猝灭, 从而不能 有效地氧化苯甲醇. 而加入NHPI后, ${ }^{\circ}{ }^{-}$自由基能够夺取NHPI中 $\mathrm{O}-\mathrm{H}$ 键的氢, 形成PINO自由基. 形成的PINO自由基能够在温和 的反应条件下氧化苯甲醇得到苯甲醛. (图1)通过调节mpg- $\mathrm{C}_{3} \mathrm{~N}_{4}$ 和NHPI的比例, 我们发现增加mpg- $\mathrm{C}_{3} \mathrm{~N}_{4}$ 的比例有利于苯甲醛的生 成. 一方面, 较低的反应温度不利于生成的醛被进一步氧化成酸. 另一方面, 由于苯甲醇和mpg- $\mathrm{C}_{3} \mathrm{~N}_{4}$ 通过O-H...N或者O-H... $\pi$ 相互 作用能够很好的吸附到 $m p g-C_{3} \mathrm{~N}_{4}$ 表面, 从而氧化为苯甲醛; 而生成的苯甲醛与 $m p g-\mathrm{C}_{3} \mathrm{~N}_{4}$ 的相互作用比较弱, 容易脱附到溶液中, 
避免被进一步的氧化. 同时, 我们也将 $m p g-\mathrm{C}_{3} \mathrm{~N}_{4} / \mathrm{NHPI}$ 催化体系拓展到其他醇类的氧化反应, 同样能够得到很好的转化率和选择 性. 该催化体系不需要任何金属元素, 利用偶合的光催化组合进行可见光催化氧化过程, 反应温度低, 为醇类分子的选择性氧化 制备醛或者酸提供了一条有效并且环保的策略。

关键词: 空气氧化; 苯甲醇; $N$-羊基邻苯酰亚胺; 自由基; 氮化碳

收稿日期: 2015-03-22. 接受日期: 2015-04-18. 出版日期: 2015-09-20.

*通讯联系人.电话: (0571)88273551; 传真: (0571)87951895; 电子信箱: chemwy@zju.edu.cn

基金来源：国家自然科学基金(21376208); 浙江省自然科学基金-杰青项目(LR13B030001); 教育部博士点基金(博导类, J20130060); 浙江省重点科技创新团队及中央高校基本科研业务费的资助.

本文的英文电子版由Elsevier出版社在ScienceDirect上出版(http://www.sciencedirect.com/science/journal/18722067). 